\title{
ANALISIS YURIDIS STATUS SEORANG DIPLOMAT AKIBAT PEMUTUSAN HUBUNGAN DIPLOMATIK DARI PERSPEKTIF KONVENSI WINA 1961 (Studi Kasus Penyerangan Kedutaan Arab Saudi di Teheran)
}

\author{
Dewa Gede Sudika Mangku \\ Program Studi Ilmu Hukum, Fakultas Hukum dan Ilmu Sosial, Universitas Pendidikan Ganesha \\ e-mail: sudika.mangku@undiksha.ac.id \\ Ni Putu Rai Yuliartini \\ Program Studi Ilmu Hukum, Fakultas Hukum dan Ilmu Sosial, Universitas Pendidikan Ganesha \\ e-mail: raiyuliartini@undiksha.ac.id
}

\begin{abstract}
ABSTRAK
Pembukaan hubungan diplomatik dan perwakilan tetap diplomatik dilakukan atas dasar kesepakatan bersama, biasanya dibuat dalam bentuk komunike bersama dan perjanjian persahabatan. Setelah itu maka kedua negara akan mengeluarkan Joint Communique yang dikeluarkan pada waktu dan tempat yang sudah disetujui bersama. Setelah ada kesepakatan bersama untuk membuka hubungan diplomatik maka pembukaan perwakilan diplomatik kedua negara bisa dilaksanakan secara timbal balik (on reciprocal basis). Prinsip kesepakatan bersama dan prinsip resiprositas merupakan dua pilar utama untuk menegakkan hukum diplomatik. Tujuan penelitian ini untuk mengetahui status seorang duta besar pada saat terjadi pemutusan hubungan diplomatik antar negara ditinjau dari Konvensi Wina 1961. Metode penelitian yang digunakan metode penelitian hukum normatif. Hasil penelitian adalah status seorang diplomat dalam hal terjadinya pemutusan hubungan diplomatik akibat konflik harus dihormati kekebalan dan keistimewaan yang diperoleh sebagaimana yang telah diatur dalam Konvensi Wina 1961 Pasal 45 sekalipun dalam hal terjadi konflik bersenjata seorang diplomat masih harus dihormati dan dilindungi missi bersama dengan semua barang dan juga arsipnya.
\end{abstract}

Kata Kunci: Konvensi Wina 1961; hubungan diplomatik; diplomat

\begin{abstract}
The establishment of diplomatic relations and diplomatic permanent representation is carried out on the basis of mutual agreement, usually in the form of joint communiqués and friendship agreements. After that, the two countries will issue a Joint Communique issued at a time and place that has been mutually agreed upon. After there is a mutual agreement to open diplomatic relations, the opening of diplomatic representatives of the two countries can be carried out on a reciprocal basis. The principle of mutual agreement and the principle of reciprocity are the two main pillars for enforcing diplomatic law. The purpose of this study was to determine the status of an ambassador at the time of termination of diplomatic relations between countries in terms of the 1961 Vienna Convention. The research method used was normative legal research methods. The result of the research is that the status of a diplomat in the event of termination of diplomatic relations due to conflict must be respected and the immunity and privileges obtained as stipulated in Article 45 of the 1961 Vienna Convention, even though in the event of an armed conflict, a diplomat must still be respected and protected by the mission along with all goods and also the archive.
\end{abstract}

Keywords: 1961 Vienna Convention; diplomatic relations; ambassador 


\section{PENDAHULUAN}

Perkembangan hukum internasional menimbulkan kebutuhan-kebutuhan baru yang berdampak nyata pada perkembangan hukum internasional. Ini juga memberikan tuntutan kepada kehidupan bernegara untuk bisa membangun relasi demi terjalinnya kerjasama untuk bisa saling melengkapi kebutuhan dari setiap negara. ${ }^{1}$ Perkembangan ini kemudian berpengaruh terhadap perkembangan hukum internasional. ${ }^{2}$ Salah satu hukum yang mengatur hubungan ini yaitu hukum diplomatik. Konvensi Wina sebagai sumber hukum diplomatik telah memberikan inspirasi bagi seluruh negara-negara di dunia, dalam melaksanakan hubungan diplomatik mereka. Pembukaan hubungan diplomatik antara negara-negara dan pembukaan perwakilan-perwakilan tetap diplomatik dilakukan atas dasar kesepakatan bersama. ${ }^{3}$ Kesepakatan ini biasanya dibuat dalam bentuk komunike bersama dan perjanjian persahabatan.

Setelah ada kesepakatan bersama mengenai pembukaan hubungan diplomatik, kemudian ada Pernyataan Bersama (Joint Communique). ${ }^{4}$ Prinsip kesepakatan bersama dan prinsip resiprositas merupakan dua pilar utama untuk menegakkan hukum diplomatik. ${ }^{5}$

Perjanjian yang telah mendapat pengakuan dari negara yang bersepakat, maka selanjutnya akan dipilih kepala perwakilan. Penunjukkan dan pengangkatan kepala perwakilan ini akan dilakukan oleh Kepala Negara dan disebut sebagai Duta Besar. ${ }^{6}$ Berdasarkan Pasal 3 Konvensi Wina Tahun

1 Hata. (2012). Hukum Internasional Sejarah dan Perkembangan Pasca Perang Dingin. Malang: Penerbit Setara, h. 3.

${ }^{2}$ Thontowi dan Iskandar. (2006). Hukum Internasional Kontemporer. Bandung: PT Refika Aditama, h. 2.

${ }^{3}$ Syahmin A.K. (2017). "Tinjauan Pelaksanaan Hukum Diplomatik Dewasa Ini”. Jurnal Hukum \& Pembangunan. 17 (6), h. 584-590.

${ }^{4}$ Prasetyo dkk. (2016). "Implikasi Pemutusan Hubungan Diplomatik Saudi Arabia Dengan Iran Pasca Eksekusi Hukuman Mati Sheikh Nimr Al-Nimr". Diponegoro Law Journal. Vol. 5 No. 3, h. 3.

${ }^{5}$ D.G.S. Mangku. (2010). "Pelanggaran Terhadap Hak Kekebalan Diplomatik (Studi Kasus Penyadapan Kedutaan Besar Republik Indonesia (KBRI) Di Yangon Myanmar Berdasarkan Konvensi Wina 1961)”, Perspektif, Vol. 15 No. 3, h. 227.

${ }^{6}$ Siregar G.E. (2020). "Pengaturan Hukum Internasional Tentang Perlindungan Pejabat Diplomatik di Negara Penerima". Lex Et Societatis. 8(2), h. 23.
1961, negara penerima berhak menolak calon duta besar yang diajukan dengan dasar perilaku ataupun kebijakan profesional dari calon di masa lalu. Bila ditolak, negara penerima tidak harus memberikan alasan penolakan tersebut kepada negara pengirim. Penerimaan duta besar dapat dicabut selama yang bersangkutan belum tiba di negara penerima. Jika telah disetujui maka perwakilan diplomatik akan menjalankan tugas-tugasnya.

Tugas seorang diplomatik dikategorikan sebagai tugas yang sangat beresiko dan tentunya membawa sebuah amanah dari negara pengirim. Perwakilan ini tentunya juga memiliki kekebalan-kekebalan yang diatur secara rinci dalam Pasal 22 sampai dengan Pasal 31 Konvensi Wina 1961. Seorang diplomat ketika menjalankan tugasnya sebagai perwakilan negara tentunya akan tetap mengikuti instruksi dari kepala negaranya. Hubungan diplomatik yang dilangsungkan antar negara tentunya tidak selalu berjalan sesuai dengan perjanjian yang dilakukan. ${ }^{7}$ Tentunya hubungan ini dapat berakhir salah satunya yaitu melalui adanya pemutusan hubungan diplomatik. Pemutusan hubungan diplomatik ini dapat dilihat dari salah satu kasus yang terjadi antara Saudi Arabia dan juga Iran. Pemutusan hubungan diplomatik antara kedua negara sudah pernah terjadi sebelumnya yaitu di tahun 1944 dan 1988. Dan ternyata di tahun 2016 pemutusan hubungan diplomatik antara kedua negara kembali terjadi. ${ }^{8}$

Pemutusan diplomatik ini dilakukan diawali dengan pemerintah Saudi Arabia yang mengeksekusi mati 47 narapidana yang menurut pihak berwenang tersangkut kasus terorisme. Salah satu dari 47 orang tersebut adalah seorang ulama ulama Syiah terkemuka Saudi yang dikenal sebagai juru kritik pemerintahan kerajaan yang berasal dari Qatif, provinsi Timur Arab Saudi, Nimr al-Nimr. ${ }^{9}$ Eksekusi

\footnotetext{
7 Siahaan N.F.E., Sutiarnoto S. dan Arif A. (2003). "Pelanggaran Hak Kekebalan Diplomatik Atas Duta Besar Italia yang Ditahan di India Ditinjau dari Hukum Internasional". Sumatra Journal of International Law. 2(1), 1499 , h. 56

${ }^{8}$ Kona S.W. (2017). "Efektivitas Pengangkatan Konsul Kehormatan Indonesia Untuk Palestina Menurut Hukum Diplomatik." Lex Et Societatis. 5(3), h. 13.

9 Bonardo Maulana Wahono. "Arab Saudi Putuskan Hubungan Diplomatik Dengan Iran". https://beritagar.id/artikel/ berita/arab-saudi-putuskan-hubungan-diplomatik-dengan-iran. Diakses pada tanggal 29 Juli 2020 Pukul 19.40 WIB.
} 
mati yang dilakukan terhadap ulama ini tentunya memberikan banyak pihak yang melakukan aksi protes, karena menganggap bahwa ulama ini adalah pencinta damai. ${ }^{10}$ Salah satunya dari Iran, aksi protes dilakukan dengan penyerangan Kedutaan Besar Arab Saudi di Teheran ${ }^{11}$ oleh orang-orang yang memprotes tindakan eksekusi tersebut. Penyerangan inilah yang menyebabkan Pemerintah Saudi Arabia memutuskan hubungan diplomatiknya dengan Iran. Pemutusan ini diumumkan pada tanggal 3 Januari 2016. "The kingdom, in light of these realities, announces the cutting of diplomatik relations with Iran and request departure of delegates of diplomatik missions of the embassy and consulate and offices related to it within 48 hours. The ambassador has been summoned to notify them." 12

Menteri Luar Negeri Arab Saudi meminta meminta diplomat Iran untuk meninggalkan kerajaan dalam waktu 48 jam. Dalam saat yang bersamaan staf misi diplomatik Arab Saudi yang ada di Teheran telah di evakuasi dan diminta untuk kembali ke Arab Saudi. Penyerangan yang dilakukan terhadap kantor Teheran di Iran dianggap sebagai sebuah pelanggaran yang fatal terhadap Hukum Internasional. Keputusan Arab Saudi dalam memutuskan hubungan diplomatik dengan Iran didorong setidaknya oleh dua faktor utama.

Pertama, Arab Saudi melihat Iran sebagai ancaman, hal ini diakibatkan oleh beberapa faktor, antara lain: nuklir Iran, persaingan minyak, serta proxy war Arab Saudi dan Iran di Suriah, Irak dan Yaman. Kedua, Arab Saudi beranggapan bahwa kapabilitas nasionalnya lebih unggul dibandingkan Iran jika dilihat dari kondisi ekonomi. Dua faktor tersebut sesuai dengan model strategi konfrontasi yang dirumuskan oleh John P. Lovell. Pemutusan dengan faktor tersebut tentunya memberikan status baru kepada diplomat yang tidak lagi menjalankan

\footnotetext{
${ }^{10}$ Indira Rezki Dari. "Irak Serukan Pemutusan Hubungan Pasca Eksekusi Ulama Syiah”. https://internasional.republika. co.id/berita/internasional/timur-tengah/16/01/03/o0c8qu328 irak-serukan-pemutusan-hubungan-pasca-eksekusi-ulama-syiah. Diakses pada tanggal 29 Juli 2020 Pukul 19.46 WIB.

11 NN. "Sikapi Ketegangan Arab Saudi-Iran, Liga Arab Kecam Iran". https://www.bbc.com/indonesia/ dunia/2016/01/160110_dunia_liga_arab_iran, diakses tanggal 29 Juli 2020 Pukul 19.50 WIB.

${ }^{12}$ RT. "Saudi Arabia cuts diplomatik ties with Iran over embassy storming". https://www.rt.com/news/327820-saudicut-ties-iran/. Diakses tanggal 29 Juli 2020 Pukul 19.54 WIB.
}

fungsinya sebagaimana diinstruksikan dalam Konvensi Wina 1969, sehingga selanjutnya status dari diplomat yang menjalankan misi diplomatik perlu diperjelas statusnya sebagai seorang diplomat. Oleh karena itulah, melalui tulisan ini akan mengkaji lebih lanjut terkait dengan bagaimana kemudian seorang diplomat termaksud perangkat dan fasilitasnya perlu dilindungi oleh negara penerima.

\section{PERUMUSAN MASALAH}

Berdasarkan uraian di atas, maka dapat ditarik suatu rumusan permasalahan sebagai berikut: bagaimana kronologi penyerangan yang terjadi pada Kedutaan Arab Saudi di Teheran Iran, serta bagaimana analisis yuridis status seorang diplomat saat terjadi pemutusan hubungan diplomatik seperti yang terjadi pada penyerangan kedutaan Arab Saudi di Teheran Iran jika dikaji dari Perspektif Konvensi Wina 1961.

\section{METODE PENELITIAN}

Metode penelitian yang digunakan pada penulisan artikel ini yaitu metode penelitian hukum normatif. ${ }^{13}$ Penelitian ini menggunakan pendekatan perundang-undangan. Secara khusus penelitian dalam hukum internasional akan mengkaji terkait dengan perspektif dari konvensi/perjanjian sebagai sumber hukum utama dalam hukum internasional. Pendekatan Kasus yaitu dengan mengkaji pada kasus penyerangan yang dilakukan terhadap Kantor Kedutaan Arab Saudi yang terletak di Teheran, serta Pendekatan Konseptual yaitu dengan mengkaji secara khusus dalam penelitian ini berbagai pandangan dan doktrin tentang status seorang diplomat jika dikaji dari perspektif Konvensi Jenewa 1961. Penelitian hukum ini menggunakan sumber bahan hukum diantaranya: Konvensi Wina 1961 tentang Hubungan Diplomatik sebagai bahan hukum primer, dan juga berbagai literatur, jurnal, berbagai penelitian serta doktrin yang berkembang terkait status seorang diplomat sebagai bahan hukum sekunder dan kamus sebagai bahan hukum tersier. Pengumpulan bahan hukum ini dilakukan dengan teknik studi dokumen. ${ }^{14}$ Bahan hukum yang telah dikumpul akan dianalisis

${ }^{13}$ Bambang Waluyo. (2002). Penelitian Hukum Dalam Praktek. Jakarta: Sinar Grafika, h.13.

${ }^{14}$ Bambang Sunggono. (2015). Metodologi Penelitian Hukum. Jakarta: Penerbit Rajawali Pers, h. 112. 
Dewa Gede Sudika Mangku dan Ni Putu Rai Yuliartini, Analisis Yuridis Status Seorang Diplomat Akibat Pemutusan Hubungan Diplomatik Dari Perspektif Konvensi Wina 1961 (Studi Kasus Penyerangan Kedutaan Arab Saudi di Teheran)

dengan menggunakan teknik deskriptif, ${ }^{15}$ evaluasi dan juga argumentasi, sehingga dapat memperoleh jawaban yang relevan terhadap permasalan yang dibahas dalam penulisan ini.

\section{PEMBAHASAN}

\section{Kronologi Penyerangan Kantor Kedutaan Arab Saudi di Teheran hingga Pemutusan Hubungan Diplomatik}

Kasus penyerangan yang dilakukan terhadap kedutaan Arab Saudi berujung pada putusnya hubungan dilplomatik antara Pemerintah Arab Saudi dan juga Iran. Pemutusan Hubungan diplomatik antara kedua negara bukan baru pertama kali terjadi tetapi justru berulang. Di tahun 1944 pemutusan hubungan diplomatik antara kedua negara diakibatkan karena adanya penahanan terhadap salah satu Jemaah iran yang membuang kotoran di Ka'bah, dan penahanan ini berakhir pada eksekusi mati. Tahun selanjutnya yaitu 1988. Pemutusan hubungan diplomatik terjadi antara kedua negara akibat adanya pengepungan yang dilakukan oleh para demonstran Iran di Kedutaan Besar Arab Saudi di Teheran akibat terjadinya demonstrasi anti Wahabi oleh Jemaah Iran di Mekkah dan berakhir pada bentrokan antara Jemaah Iran dan petugas keamanan Arab Saudi.

Penyerangan yang dilakukan terhadap Kantor Kedutaan diawali dengan adanya kasus eksekusi mati terhadap Sheik Nimr al-Nimr, yang merupakan warga negara Arab Saudi yang selalu melakukan protes terhadap setiap kebijakan dari Pemerintah Arab Saudi. ${ }^{16}$ Eksekusi mati yang dilakukan terhadap ulama Sheik dilaksanakan pada tanggal 2 Januari 2016. Pemerintah Arab Saudi melalui menteri Luar Negeri Jubeir mengakatan bahwa tindakan eksekusi yang dilakukan adalah tindakan yang benar. Hal ini dikarenakan eksekusi dilakukan terhadap 43 orang Al Qaedah dan 4 orang Syiah yang dinggap sebagai teroris dan juga pihak-pihak yang melawan pemerintah, salah satu dari mereka yaitu ulama Sheik. Pasca eksekusi mati yang dilakukan terhadap ulama Sheik, bebera waktu kemudian penyerangan dilakukan oleh beberapa warga dari Iran terhadap Kedutaan Arab Saudi di Taheran.

\footnotetext{
15 Amiruddin dan Asikin. (2018). Pengantar Metode Penelitian Hukum. Depok: PT Raja Grafindo Persada, h. 174.

${ }^{16}$ Prasetyo dkk. op.cit., h. 6.
}

Penyerangan ini diawali dengan adanya ancaman yang diberikan terhadap staf kedutaan Arab Saudi yang diterima dan disambungkan melalui telepon. Selain itu, penyerangan dilakukan menggunakan sebuah taksi yang masuk secara paksa ke dalam gedung konsulat melintasi batas keamanan, namun tidak ada pencegahan yang dilakukan oleh otoritas Iran. Sekelompok orang berkerumun di depan kantor kedutaan besar Arab Saudi di Teheran dengan jumlah mereka yang mencapai kurang lebih 2000 orang. Mereka tidak hanya datang sekedar untuk melakukan aksi protes tetapi mereka juga mengambil bom. ${ }^{17} \mathrm{Bom}$ yang diambil kemudian dilemparkan ke dalam dan mengarah pada kaca kantor kedubes. Kondisi tersebut membuat konsulat jendral melakukan komunikasi dengan Kementrian Luar Negeri dari Iran untuk meminta perlindungan, namun usaha tersebut justru tidak mendapatkan hasil dan sia-sia. ${ }^{18}$ Penyerangan terus dilakukan sebagian kelompok yang melakukan penyerangan terhadap gedung kantor kedutaan besar Arab Saudi di Teheran melemparkan batu dan juga bom untuk menghancurkan gedung tersebut. Usaha untuk menghubungi pihak Kemenlu dan Pemerintah Iran justru tidak berhasil. Listrik di tempat tinggal dari kedutaan juga terputus selama satu jam. Setelah massa telah selesai melakukan penyerangan, Konsulat Jendral Saudi melakukan pemeriksaan terhadap kantor kedutaan yang telah diserang.

Pasca penyerangan dilakukan bangunan kantor kedubes di Teheran hancur, fasilitas gedung mengalami kerusakan yang sangat parah, dan juga banyak perangkat dan furnitur yang dicuri oleh para demonstran. Tindakan ini menyebabkan kekecewaan dari Arab Saudi, ${ }^{19}$ tidak hanya terkait penyerangan tersebut tetapi juga pemerintah Iran yang gagal dan bahkan tidak berupaya untuk menghentikan penyerangan yang dilakukan terhadap Kantor Kedutaan Besar Arab Saudi di Teheran. Atas insiden tersebut yang terjadi, pemerintah Arab Saudi memanggil duta besar Iran untuk Arab Saudi kemudian memberikan nota protes terhadap pemerintah Iran, dan meminta pertanggungjawaban terhadap penyerangan yang telah dilakukan di kantor Kedutaan, karena sudah seharusnya pemerintah Iran memberikan perlindungan terhadap warga asing yang

\footnotetext{
17 ibid., h. 6.

18 ibid.

19 ibid., h. 7.
} 
sedang menjalakan misi atau bertugas di negaranya, sebagaimana hal ini sesuai dengan perjanjian internasional.

Pemberian nota protes ini diikuti dengan pemutusan hubungan diplomatik yang diumumkan oleh Pemerintah Arab Saudi. Pada tanggal 3 Januari 2016 Pemerintah Arab Saudi secara resmi mengumumkan dan memutuskan untuk melakukan penarikan terhadap semua diplomat dari negara Iran untuk kembali ke Arab Saudi. Pemerintah Arab Saudi juga sekaligus melakukan pengusiran terhadap seluruh diplomat Iran yang ada di Arab Saudi dalam tempo 48 jam setelah kejadian tersebut. Pernyataan yang dikeluarkan oleh Pemerintah Suriah melalui Menteri Luar Negeri Arab Saudi tidak hanya tentang kewajiban Iran dalam pengusiran terhadap para perwakilan Iran di Arab, tetapi juga memberikan pernyataan yang secara tersirat bahwa Iran terlalu sering untuk ikut campur dalam masalah internal dari negara lain yang justru memberikan dampak negatif seperti kerugian, kehancuran, bahkan juga pembunuhan jiwa-jiwa yang bersalah. Sehingga Pemerintah Suriah menyatakan bahwa tindakan lalai Pemerintah Iran dalam penanganan kasus penyerangan ini merupakan pelanggaran fatal. Iran dinilai telah melanggar peraturan internasional, sehingga beberapa negara koalisi Arab mengikuti langkah Arab Saudi dalam mengasingkan Iran.

Setelah kejadian ini Pemerintah Iran, pada tanggal 4 Januari 2016 melakukan penyuratan kepada Sekretaris Jendral Perserikatan Bangsa-Bangsa, dalam surat yang bernomor 3319. Surat tersebut berisikan pengakuan Iran dan juga penyesalan terhadap tindakan penyerangan yang telah dilakukan oleh para demonstran, baik membakar maupun menyerang kantor Kedutaan Besar Arab Saudi di Taheran atas protes mereka terhadap kebijakan eksekusi mati ulama Sheikh. Pemerintah Iran juga menyampaikan bahwa telah berupaya melakukan beberapa langkah untuk massa yang telah melakukan unjuk rasa dan amuk di kedubes Arab Saudi, namun tidak dapat dikendalikan. Pemerintah Iran melalui penulisan surat ini pada akhirnya berjanji untuk akan mencegah insiden serupa di masa yang akan datang. Sebagai bentuk permohonan maaf Pemerintah Iran juga berjanji untuk akan segera menyelesaikan masalah ini dengan menghukum dan mengadili semua demonstran yang telah melakukan penyerangan terhadap kantor kedubes Arab Saudi di Teheran.

Analisis Yuridis Status Seorang Diplomat Saat Terjadi Pemutusan Hubungan Diplomatik Yang Terjadi Pada Penyerangan Kedutaan Arab Saudi di Teheran Iran

\section{Pertama, Kekebalan Seorang Diplomat}

Kekebalan duta besar dari yurisdiksi pidana di negara penerima telah dimulai dilakukan oleh berbagai negara pada abad ke-17 sebagai kebiasaan internasional. Salah satu kasus yang terjadi di Tahun 1706 antara Britania Raya dan Russia, ketika duta besar Russia ditangkap karena tuduhan kasus penipuan, ${ }^{20}$ hal ini kemudian menyebabkan Russia menuntut permintaan maaf, jika tidak akan diselesaikan melalui cara berperang. Meski demikian pemerintah Inggris telah mengajukan rancangan undang-undang di kedua majelis parlemen yang menyatakan bahwa "setiap wakil asing harus dianggap suci dan tidak dapat diganggu gugat" (inviolability). ${ }^{21}$

Disamping itu undang-undang ini juga memuat ketentuan bahwa para diplomat asing dibebaskan dari yurisdiksi perdata dan pidana. Undang-undang inilah yang kemudian terkenal sebagai "7 Anne Cap. 122.706" yang ternyata dokumen tersebut menjadi dasar bagi kekebalan dan keistimewaan para diplomat. ${ }^{22}$ Kekebalan diplomatik tidak hanya dinikmati oleh kepala-kepala perwakilan seperti duta besar, duta atau kuasa usaha (charge d'affaires) tetapi juga oleh anggota keluarganya yang tinggal bersamanya, termasuk para diplomat lain yang menjadi anggota perwakilan, seperti counsellor, para sekretaris, atase dan sebagainya. ${ }^{23}$. Penerima kekebalan diplomatik ini juga secara jelas diatur di dalam Pasal 37 Konvensi Wina 1961, diantaranya disebutkan bahwa kekebalan dan keistimewaan diplomatik diberikan kepada:

a. Para pejabat perwakilan diplomatik meliputi ambassador, Minister, Minister Counsellor, counsellor, secretary, and Attache, serta pejabatpejabat konselerasi, dan lain-lain;
20 ibid.
21 ibid., h. 70.
22 ibid.
23 ibid. 
b. Pembantu-pembantu pribadi kepala perwakilan, pembantu rumah tangga, pengasuh anak, sekretaris pribadi, dan sebagainya;

c. Anggota keluarga kepala perwakilan, anggota terdekat yang seumuran atau tinggal bersama dengan kepala perwakilan;

d. Kurir diplomatik dan lain sebagainya.

Perwakilan diplomatik yang dikirimkan oleh setiap negara ke negara lainnya telah dianggap memiliki suatu sifat suci secara khusus. Sebagai konsekuensinya, mereka diberikan kekebalan dan keistimewaan diplomatik tersebut. Meski demikian dijelaskan pula pada Pasal 32 Konvensi Wina 1961 bahwa kekebalan dari kekuasaan hukum yang dimiliki para pejabat diplomatik dan orangorang yang menikmati kekebalan sebagaimana yang disebutkan di dalam Pasal 37 tersebut dapat ditanggalkan (waived) oleh negara pengirim. ${ }^{24}$

a. Menurut Teori Pemberian Kekebalan dan Keistimewaan Bagi Seorang Diplomat

Jika dilihat berdasarkan teori yang berkembang terdapat 3 macam teori yang menjadi landasan pemberian kekebalan dan keistimewaan bagi seorang diplomat. ${ }^{25}$ Teoriteori ini kemudian berkembang dan seiring berjalannya waktu menjadi landasan dalam setiap penyusunan instrument-instrumen hukum internasional terkait dengan hubungan diplomatik. Teori tersebut diantaranya:

1) Exterritoriality Theory. Menurut teory ini seorang pejabat diplomatik dianggap tidak berada di negara penerima melainkan berada di dalam negara pengirim, meskipun kenyataannya dia berada di wilayah negara penerima. ${ }^{26}$ Yang dimaksud dalam hal ini adalah bahwa seseorang yang mewakili negaranya di negara penerima sebagai seorang diplomat tetap tunduk pada hukum dan yurisdiksi nasional atau yang ada di negara asalnya, sehingga yang berlaku

${ }^{24}$ Ananda dkk. (2017). “Akibat Hukum Penanggalan Kekebalan (Immunity Waiver) Kepada Pejabat Diplomatik Ditinjau Dari Konvensi Wina 1961 (Studi Kasus Penanggalan Kekebalan Terhadap Asisten Atase Militer Malaysia Di Selandia Baru Tahun 2014).” Diponegoro Law Journal, Vol. 6 No. 2, h. 5.

${ }^{25}$ Lasut W. (2016). "Penanggalan Kekebalan Diplomatik di Negara Penerima Menurut Konvensi Wina 1961.” Lex Crimen, 5(4), h. 71.

${ }^{26}$ Setyo Widagdo dan Hanif Nur W., op.cit., h. 73. dalam wilayah kantor perwakilan ataupun tempat kediamannya adalah aturan hukum dari negara asalnya. Pada abad ke 16 dan 17, teori ini sangat menonjol dan sering digunakan dalam pemberian kekebalan dan keistimewaan diplomatik, dimana wakil diplomatik dianggap bukan sebagai subjek hukum dari negara penerima. ${ }^{27}$

2) Representative Character Theory. "Par im parem non habet imperium. " Artinya, negara yang berdaulat tidak dapat menjalankan yurisdiksi terhadap negara berdaulat lainnya. Oleh karena itu, pejabat diplomatiknya harus diberi hak kekebalan dan hak keistimewaan. ${ }^{28}$ Di dalam teori ini pada pokoknya menjelaskan bahwa kedudukan ataupun status dari seorang wakil diplomatik dipersamakan dengan kedudukan seorang kepada negara atau negara pengirim itu sendiri, ${ }^{29}$ sehingga wajib untuk mendapatkan kekebalan dan keistimewaan sebagai sebuah konsekuensi adanya kedaulatan negara pengirim di negara penerima yang tidak dapat dinganggu gugat.

3) Functional Necessity Theory. Jika dilihat dalam perkembangannya, teori ini juga memberikan suatu dasar dan secara tersirat diatur di dalam Konvensi Wina 1961, seperti yang tertera dalam pembukaan atau preambulnya pada alinea ketiga yang berbunyi: "The purpose of such previleges and immunities is not benefit individuals but not to ensure the efficient performance of the functions of diplomatik missions as representing state". Teori ini memberikan suatu ketentuan bahwa seorang diplomat dalam melaksanakan tugasnya harus dilaksanakan tanpa gangguan, sehingga tugas yang dijalankan dapat dikerjakan secara efektif dan efisien.

\section{b. Menurut Konvensi Wina 1961}

Konvensi Wina 1961 pada pasal yang ke-29 secara jelas mengatur tentang kekebalan pribadi yang dimiliki oleh seorang diplomat, yang menyebutkan: "Pejabat diplomatik tidak boleh

\footnotetext{
27 ibid.

${ }^{28}$ ibid., h. 76.

${ }^{29}$ ibid., h. 77.
} 
diganggu-gugat. Pejabat diplomatik tidak boleh ditangkap dan ditahan. Negara penerima harus memperlakukannya dengan penuh hormat dan mengambil langkah yang layak untuk mencegah serangan atas diri, kebebasan dan martabat seorang diplomat". Tidak hanya seorang diplomat atau konteks berbicara tentang individu tetapi juga tempat ataupun kantor seorang diplomat. ${ }^{30}$ Pasal 22 dan 33 Konvensi Wina 1961 dinyatakan bahwa tempat kediaman dan gedung perwakilan diplomatik mempunyai hak kekebalan. ${ }^{31}$ Konvensi Wina 1961 terdapat beberapa pasal yang memberikan suatu dasar adanya jaminan kekebalan bagi seorang diplomat.

Dengan kata lain, bahwa negara penerima memiliki hak dan kewajiban yang sebatas hanya untuk menjaga kepentingan nasional negara penerima dan untuk memenuhi hak dan kewajiban yang sudah disepakati dalam perjanjian diplomatik guna untuk kelancaran pelaksanaan tugas dari seorang perwakilan diplomat dan tetap menghargai hak-hak dari negara pengirim ${ }^{32}$. Sehingga dalam konteks ini kekebalan dan keistimewaan yang diberikan dalam pasal-pasal ini adalah suatu ketentuan hukum internasional yang harus dihormati oleh masing-masing negara yang bersepakat untuk mengirimi perwakilan negaranya untuk melaksanakan misi diplomatik di negara lain. ${ }^{33}$

\section{Kedua, Status Seorang Diplomat ketika Pemutusan Hubungan Diplomatik Kasus Arab Saudi dan Iran}

Pasal 39 ayat (1) Konvensi Wina 1961 berbunyi: "every person entitled to previlages and immunities shall enjoy them from the moment the enters the territory of the receiving state on proceeding to

${ }^{30}$ Syafiza K., Arif A. dan Leviza J. (2014). “Tinjauan Hukum Internasional Mengenai Eksistensi Konsul Kehormatan (Honorary Consul) dalam Hubungan Konsuler (Studi Kasus: Konsul Kehormatan Jerman di Medan). Sumatra Journal of International Law, 2(1), 14-99, h. 45.

31 Fitriyadi A.A. \& Latukau F. (2020). "Diferensiasi Pengungsi dan Pencari Suaka Dalam Hukum Pengungsi Internasional dan Hubungannya Dengan Prinsip NonRefoulement." Jambura Law Review. 2(2), h. 120-138.

32 C.G. Pandean. (2016). "Hak dan Kewajiban Hukum Negara Penerima Terhadap Diplomat Menurut Konvensi Wina Tahun 1961.” Lex Privatum, Vol. 4 No. 4, h. 113.

${ }^{33}$ Mangku D.G.S. (2017). "Penerapan Prinsip Persona Non Grata (Hubungan Diplomatik Antara Malaysia dan Korea Utara)." Jurnal Advokasi. 7(2), h. 135-148. take up his post or, if already in it's territory, from moment when he appointment is notified to the ministry for foreign affairs or such other ministry as may be agreed". Pasal ini memberikan penjelasan bahwa setiap orang yang berhak mendapat kekebalan dan hak-hak istimewa akan mulai menikmatinya semenjak ia memasuki wilayah negara penerima, dalam perjalanannya untuk memangku jabatannya, atau jika ia sudah berada di wilayah negara penerima, dan mulai menikmatinya sejak pengangkatannya diberitahukan kepada kementrian luar negeri atau kepada kementrian lainnya sebagaimana telah disetujui. ${ }^{34}$ Ini sebagai awal dari dimulainya pemberlakuan terhadap kekebalan yang diperoleh oleh seorang diplomat, sehingga wajib dihormati oleh negara penerima. Konvensi wina 1961 negara penerima harus memperlakukan perwakilan diplomat seperti seorang kepala negara. Namun, kekebalan yang diberikan ini tidak kemudian menjadi suatu alasan untuk perwakilan diplomatik di negara penerima dapat bertindak semena-mena. ${ }^{35}$

Pasal 41 ayat (1), (3), dan juga Pasal 42 konvensi Wina 1961 memberikan kewajiban dan larangan bagi agen diplomatik sebagai bentuk batasan ketika menjalani missi. Kewajiban tersebut yaitu: a. Gedung misi tidak boleh dipergunakan secara tidak selaras dengan fungsi missi sebagai yang dituangkan dalam konvensi ini, atau aturan-aturan internasional atau perjanjian khusus yang berlaku di antara negara pengirim dan negara penerima; $b$. semua orang yang mendapat hak-hak istimewa dan kekebalan hukum tanpa merugikan hak-hak istimewa dan kekebalan hukum mereka, harus: menghormati hukum dan peraturan negara penerima dan tidak mencampuri urusan dalam negeri negara penerima. ${ }^{36}$ Larangan bagi agen diplomatik ialah mereka tidak boleh di dalam negara penerima itu melakukan untuk keuntungan pribadinya, sesuatu kegiatan professional atau perdagangan. ${ }^{37}$ Kasus penyerangan yang dilakukan terhadap gedung perwakilan kedutaan Arab Saudi di Teheran, tidak terjadi karena adanya pelanggaran

${ }^{34}$ Setyo Widagdo dan Hanif Nur W., op.cit., h. 84.

${ }^{35}$ Wulan A.R. (2017). "Pelaksanaan Kekebalan Diplomatik Dalam Konvensi Wina 1961 Perspektif Siyasah Dauliyah." ADLIYA: Jurnal Hukum dan Kemanusiaan. 11(2), h. 191-212.

${ }^{36}$ Wasito. (1984). Konvensi Konvensi Wina Tentang Hubungan Diplomatik, Hubungan Konsuler dan Hukum Perjanjian/Traktat. Yogyakarta: Penerbit Andi Offset, h. 18.

37 ibid. 
dari agen diplomatik terhadap kewajiban ataupun larangan yang yang disebutkan sebelumnya, sehingga hal inilah yang menyebabkan penyerangan yang dilakukan terhadap gedung perwakilan diplomatik Arab Saudi di Teheran adalah bentuk pelanggaran terhadap Konvensi Wina 1961.38

Penyerangan terjadi akibat eksekusi mati dari ulama, sehingga seharusnya aksi protes yang dilakukan bisa langsung melalui Arab Saudi, karena agen diplomatik Arab Saudi di Teheran, masih dalam status memiliki kekebalan dan keistimewaan sebagai perwakilan diplomatik yang harus dilindungi dan dijaga. Jika dibandingkan dengan kebijakan yang dikeluarkan oleh Pemerintah Arab Saudi bahwa ketika terjadi penyerangan kedutaan besar di Iran, Hal ini tidak membuat pemerintah Arab Saudi melakukan penyerangan juga terhadap kedutaan besar negara Iran di Arab Saudi. Tetapi justru melalui kementrian luar negeri, memberikan pengumuman pengusiran terhadap Kedutaan Besar Iran yang ada di Arab Saudi dalam jangka waktu 48 jam. Seorang Duta Besar dapat diusir, tetapi tidak dapat ditangkap, ditahan, ataupun diadili di negara penerima. ${ }^{39}$

Kasus yang terjadi antara Arab Saudi dan Iran ketika penyerangan gedung perwakilan kedutaan Arab Saudi di Iran, tentunya pada saat ini perwakilan dari masing-masing agen diplomatik masih ada di negara penerima. Waktu yang bersamaan ketika penyerangan itu dilakukan selang beberapa jam pemerintah Arab Saudi melakukan pengumuman dengan memutuskan hubungan diplomatik antara kedua negara, hal ini tentunya bukan berakhir dikarenakan fungsi dan tugasnya yang sudah selesai sebagaimana yang diatur Pasal 9 ayat (2) Konvensi Wina 1961 maupun Pasal 43. Akan tetapi pemutusan ini terjadi akibat adanya penyerangan yang dilakukan terhadap gedung perwakilan Arab Saudi di Iran. Ketika terjadi pemutusan sebelum adanya pengakhiran tugas dari fungsi diplomatik tentunya akan memberikan konteks dan juga status yang diperoleh dalam situasi tersebut kepada perwakilan diplomatik.

${ }^{38}$ Tambun A., Monalisa N., Sutiarnoto S., \& Arif A. (2013). "Penerobosan dan Perusakan Gedung Konsulat Amerika Serikat di Benghazi, Libya Ditinjau dari Hukum Diplomatik." Sumatra Journal of International Law, 1(2), h. 14-97.

${ }^{39}$ Setyo Widagdo dan Hanif Nur W. op.cit., h. 69.
Jika ditinjau dari pasal ini, secara jelas bahwa meskipun terjadi pemutusan hubungan diplomatik, negara penerima harus tetap melindungi dan menghormati setiap missi dengan semua barangbarang yang dimiliki oleh negara pengirim. Artinya bahwa ketika terjadi pemutusan hubungan diplomatik, status seorang diplomat masih harus dihormati dan dilindungi semua kekebalan dan keistimewaan yang diterimanya sesuai konvensi Wina 1961. Bahkan jika terjadi konflik bersenjata. Sehingga, ketika konflik yang terjadi antara Arab Saudi dan Iran terjadi, saat Arab Saudi memutuskan hubungan diplomatik, Baik Arab Saudi maupun Iran harus tetap menghormati dan melindungi hak-hak dari seorang Diplomat ketika melakukan pengusiran. Selain itu, negara pengirim juga bisa mempercayakan pemeliharaan gedung misi dan semua peralatannya dan arsipnya kepada negara ketiga dan juga perlindungan warga negaranya kepada negara ketiga yang diterima juga oleh negara penerima. hal ini mengindikasikan bahwa dalam hal terjadinya konflik ataupun pemutusan hubungan diplomatik sekalipun, selama masih dalam jangka waktu yang ditentukan untuk pengusiran ataupun evakuasi perwakilan diplomatik untuk kembali ke negaranya, agen diplomatik baik dari Arab Saudi maupun Iran harus dihormati dan dilindungi hak-haknya.

\section{PENUTUP \\ Kesimpulan}

Berdasarkan pembahasan yang telah dilakukan di atas, maka dapat disimpulkan bahwa:

Kronologi penyerangan yang dilakukan terhadap gedung perwakilan kedutaan Arab Saudi di Teheran dipicu oleh adanya aksi protes yang dilakukan oleh sebagian massa yang menuntut kebijakan dari Pemerintah Arab Saudi. Atas kebijakan eksekusi mati terhadap salah satu ulama Sheik Nimr al-Nimr, yang dilakukan terhadap ulama Sheik dilaksanakan pada tanggal 2 Januari 2016. Penyerangan kedutaan Arab Saudi di Taheran dilakukan oleh kurang lebih 2000 orang setelah eksekusi mati, dan penyerangan ini diawali dengan ancaman terhadap staf perwakilan diplomatik, perusakan gedung, pelemparan batu, hingga penggunaan bom yang merusakkan seluruh fasilitas dan gedung perwakilan kedutaan Arab Saudi di Teheran, sehingga hal ini menyebabkan di tanggal 3 Januari 2016 Pemerintah Arab Saudi melakukan 
evakuasi dan penarikan agen diplomatik di Iran, dan memberikan nota protes kepada perwakilan diplomatik Iran di Arab Saudi. Dan secara resmi juga mengumumkan pemutusan hubungan diplomatik antara kedua negara serta melakukan pengusiran terhadap agen diplomatik Iran di Arab Saudi.

Status seorang diplomat dalam hal terjadinya pemutusan hubungan diplomatik akibat konflik, sebagaimana yang terjadi antara Arab Saudi dan Iran, jika ditinjau dari perspektif Konvensi Wina 1961 tentang Hubungan Diplomatik, bahwa seorang diplomat masih tetap harus dihormati kekebalan dan keistimewaan yang diperoleh sebagaimana yang telah diatur dalam konvensi Wina 1961, dan secara jelas diatur di dalam Pasal 45 sekalipun dalam hal terjadi konflik bersenjata seorang diplomat masih harus dihormati dan dilindungi missi bersama dengan semua barang dan juga arsipnya. Baik negara penerima maupun negara pengirim harus bisa menerapkan dan berpegang teguh pada Konvensi Wina 1961 sebagai landasan hukum untuk bisa membangun relasi lebih baik, dan tentunya secara jelas memahami bahwa ada batasan dan juga kebijakan dari masing-masing negara yang tidak dapat di intervensi baik dari negara penerima maupun negara pengirim. Dan seorang diplomat dalam kondisi apapun sudah seharusnya tetap dijaga dan dilindungi kehormatannya sebagai perwakilan negaranya. Dan dengan harapan dalam kasus yang terjadi antara Iran dan Arab Saudi, Iran bisa lebih mengendalikan masyarakat di negaranya dan menggunakan cara yang lebih diplomatis untuk bisa menyelesaikan masalah karena kebijakan dari Arab Saudi terhadap warga negara adalah bagian dari kebijakan internal yang tidak dapat diganggu gugat, sehingga penyerangan terhadap perwakilan diplomatik di Teheran adalah pelanggaran yang harus segera diselesaikan antara kedua negara.

\section{DAFTAR PUSTAKA}

\section{Buku:}

Amiruddin dan Asikin. (2018). Pengantar Metode Penelitian Hukum. Depok: PT Raja Grafindo Persada.

Bambang Sunggono. (2015). Metodologi Penelitian Hukum. Jakarta: Penerbit Raja Wali Pers.

Bambang Waluyo. (2002). Penelitian Hukum Dalam Praktek. Jakarta: Sinar Grafika.
Hata. (2012). Hukum Internasional Sejarah dan Perkembangan Pasca Perang Dingin. Malang: Penerbit Setara.

Thontowi dan Iskandar. (2006). Hukum Internasional Kontemporer. Bandung: PT Refika Aditama.

Wasito. (1984). Konvensi Konvensi Wina Tentang Hubungan Diplomatik, Hubungan Konsuler dan Hukum Perjanjian/Traktat. Yogyakarta: Penerbit Andi Offset.

\section{Jurnal:}

Ananda dkk. (2017). “Akibat Hukum Penanggalan Kekebalan (Immunity Waiver) Kepada Pejabat Diplomatik Ditinjau Dari Konvensi Wina 1961 (Studi Kasus Penanggalan Kekebalan Terhadap Asisten Atase Militer Malaysia Di Selandia Baru Tahun 2014).” Diponegoro Law Journal. Vol. 6 No. 2, h. 5.

C.G. Pandean. (2016). "Hak dan Kewajiban Hukum Negara Penerima Terhadap Diplomat Menurut Konvensi Wina Tahun 1961." Lex Privatum. Vol. 4 No. 4, h. 113.

D.G.S. Mangku. (2010). "Pelanggaran Terhadap Hak Kekebalan Diplomatik (Studi Kasus Penyadapan Kedutaan Besar Republik Indonesia (KBRI) Di Yangon Myanmar Berdasarkan Konvensi Wina 1961)." Perspektif. Vol. 15 No. 3, h. 227.

Fitriyadi A.A. \& Latukau F. (2020). "Diferensiasi Pengungsi dan Pencari Suaka dalam Hukum Pengungsi Internasional dan Hubungannya dengan Prinsip Non-Refoulement." Jambura Law Review. 2(2), h. 120-138.

Kona S.W. (2017). "Efektivitas Pengangkatan Konsul Kehormatan Indonesia Untuk Palestina Menurut Hukum Diplomatik." Lex Et Societatis. 5(3), h. 13.

Lasut W. (2016). "Penanggalan Kekebalan Diplomatik di Negara Penerima Menurut Konvensi Wina 1961.” Lex Crimen. 5(4), h. 71. Mangku D.G.S. (2017). "Penerapan Prinsip Persona Non Grata (Hubungan Diplomatik Antara Malaysia dan Korea Utara)." Jurnal Advokasi. 7(2), h. 135-148.

Prasetyo dkk. (2016). "Implikasi Pemutusan Hubungan Diplomatik Saudi Arabia Dengan Iran Pasca Eksekusi Hukuman Mati Sheikh Nimr AlNimr". Diponegoro Law Journal. Vol. 5 No. 3, h. 3 . 
Dewa Gede Sudika Mangku dan Ni Putu Rai Yuliartini, Analisis Yuridis Status Seorang Diplomat Akibat Pemutusan Hubungan Diplomatik Dari Perspektif Konvensi Wina 1961 (Studi Kasus Penyerangan Kedutaan Arab Saudi di Teheran)

Siahaan N.F.E., Sutiarnoto S. dan Arif A. (2003). "Pelanggaran Hak Kekebalan Diplomatik Atas Duta Besar Italia yang Ditahan di India Ditinjau dari Hukum Internasional". Sumatra Journal of International Law. 2(1), 14-99, h. 56.

Siregar G.E. (2020). "Pengaturan Hukum Internasional tentang Perlindungan Pejabat Diplomatik di Negara Penerima". Lex Et Societatis. 8(2), h. 23.

Syafiza K., Arif A. dan Leviza J. (2014). “Tinjauan Hukum Internasional Mengenai Eksistensi Konsul Kehormatan (Honorary Consul) dalam Hubungan Konsuler (Studi Kasus: Konsul Kehormatan Jerman di Medan)". Sumatra Journal of International Law, 2(1), 14-99, h. 45.

Syahmin A.K. (2017). "Tinjauan Pelaksanaan Hukum Diplomatik Dewasa Ini”. Jurnal Hukum \& Pembangunan. 17 (6), h. 584-590.

Tambun A., Monalisa N., Sutiarnoto S., \& Arif A. (2013). "Penerobosan dan Perusakan Gedung Konsulat Amerika Serikat di Benghazi, Libya Ditinjau dari Hukum Diplomatik." Sumatra Journal of International Law, 1(2), h. 14-97.

Wulan A.R. (2017). "Pelaksanaan Kekebalan Diplomatik Dalam Konvensi Wina 1961
Perspektif Siyasah Dauliyah.” ADLIYA: Jurnal Hukum dan Kemanusiaan. 11(2), h. 191-212.

\section{Website:}

Bonardo Maulana Wahono. "Arab Saudi Putuskan Hubungan Diplomatik Dengan Iran”. https:// beritagar.id/artikel/berita/arab-saudi-putuskanhubungan-diplomatik-dengan-iran. Diakses pada tanggal 29 Juli 2020 Pukul 19.40 WIB.

Indira Rezkisari. "Irak Serukan Pemutusan Hubungan Pasca Eksekusi Ulama Syiah”. https://internasional.republika.co.id/berita/ internasional/timur-tengah/16/01/03/ o0c8qu328-irak-serukan-pemutusan-hubunganpasca-eksekusi-ulama-syiah. Diakses pada tanggal 29 Juli 2020 Pukul 19.46 WIB.

NN. "Sikapi Ketegangan Arab Saudi-Iran, Liga Arab Kecam Iran". https://www.bbc.com/indonesia/ dunia/2016/01/160110_dunia_liga_arab_iran, diakses tanggal 29 Juli 2020 Pukul 19.50 WIB.

RT. "Saudi Arabia cuts diplomatik ties with Iran over embassy storming". https://www.rt.com/ news/327820-saudi-cut-ties-iran/. Diakses tanggal 29 Juli 2020 Pukul 19.54 WIB. 